\title{
FINANCING EFFICIENCY AND ITS EFFECT TO LECTURER PERFORMANCE AND STUDENT LEARNING OUTCOMES ON PRIVATE COLLEGE
}

\author{
Nano Sukmana \\ Langlangbuana University, Bandung, Indonesia \\ nanosukmana@unla.ac.id
}

\begin{abstract}
This study is entitled to the efficiency of funding and its influence on the performance of Lecturers and Student Learning Outcomes. The focus of the study is on how the efficiency of funding affects the performance of Lecturers and Student Learning Outcomes. The research method used is quantitative, using statistical tests: Correlation Analysis, Regression, and Path Analysis. Both the lecturer's performance and student learning outcomes. This finding shows the importance of financing that is managed efficiently and protected from various types of waste, misuse, and violations of various stipulations. The results of this study are that the Efficiency of Financing significantly influences both the performance of lecturers and the results of student learning. This finding shows how important funding is managed efficiently and avoiding various types of waste, misuse, and violations of various stipulated provisions. Lecturer performance and student learning outcomes are strategic factors that can determine the level of institutional performance achievement of Private Universities that are studied clearly and reliably.
\end{abstract}

Keywords: Financing Efficiency, Lecturer Performance, Student Learning Outcomes, Institutional Performance of Private Universities

\section{INTRODUCTION}

The cost function in educational institutions such as Higher Education is basically to support the provision of facilities and infrastructure, such as land, buildings, laboratories, libraries, learning media, teaching operations, administrative services, and so on. The actual cost of education is not always synonymous with money (real cost), but also everything that is sacrificed for each activity to achieve the objectives of education.

Private tertiary institutions, as an organization, have objectives, functions, and basic tasks that are different from other organizations. The main purpose, function, and task of a Higher Union are to improve welfare or for the public interest, not for the benefit of a particular individual or group of people, but in reality, it is difficult to avoid such things, especially in dealing with the current economic situation. So, in its development plans, sometimes things that are not allowed to be done by nonprofit organizations such as Higher Education, such as publication efforts to attract more prospective students.
Lecturer performance is something that should get serious attention to a university because lecturers are the spearhead in the learning process. The role of lecturers in improving institutional performance is very decisive so that in this study discussed the influence of lecturer performance on student learning outcomes.

Learning is the process or effort made by each individual to obtain a change in behavior both in the form of knowledge, skills, and attitudes and positive values as an experience to get several impressions from the material that has been learned. Learning activities are carried out on campus, at home, and in other places such as in museums, in laboratories, in the forest, and everywhere. Learning is a complex student's action and behavior. As an action, learning is only experienced by students themselves and will be a determinant of the occurrence or nonoccurrence of the learning process.

Efficiency for Private Universities is not only on the strategic factor to carry out institutional programs, but also, in 
particular, is the thing that influences lecturer performance. Lecturers who carry out their main tasks require the support of matters relating to the fulfillment of basic needs for life, such as salary, benefits, and health insurance.

All of these basic elements are impossible if they are not supported by financing that is used carefully, appropriately and avoids wastefulness, misuse of the stipulated financing rules.

Based on the description above, research on financing efficiency about efforts to improve lecturers' performance and student learning outcomes has been carried out following scientific principles.

According to Ahmad \& Wasilah (2009) costs (costs) are expenses or the value of sacrifice to obtain goods or services that are useful for the future, or have benefits exceeding an annual period. Usually reflected in the balance sheet as assets (assets) of the company. Costs in the broad sense are as follows: "Cost in the broad sense is the sacrifice of economic resources, measured in units of money, which have occurred or are likely to occur for a particular purpose".

According to Bustami \& Nurlela (2009) the cost is the sacrifice of economic resources measured in units of money that have occurred or are likely to occur to achieve certain goals. These costs have not expired, and are classified as assets included in the balance sheet. Cost object (cost object) is a basis that is used to perform cost calculations. Cost objects include products, services, projects, consumers, brands, activities, and departments.

Financing Efficiency according to Bustami \& Nurlela (2009) is as follows: (1) Based on the cost object: Cost object (cost object) is a basis that is used to perform cost calculations. Cost objects include products, services, projects, consumers, brands, activities, and departments; (2) Cost behavior: Categorized into three types of costs. Namely: variable costs are costs that in total change directly with the change in the level of activity or volume. Fixed costs are costs that do not change totally with the level of change in the level of activity or volume within the limits of the relevant level of activity or a certain period. Semi-variable costs are costs that have or contain fixed elements and variable elements; (3) Accounting period: Costs are differentiated based on time or when they are charged to revenue. The period of an accounting period is generally 1 year, and at the end of the period, the company makes an Annual Financial Report; (4) Management function: Classification costs: operational costs

Private tertiary institutions, as an organization, have objectives, functions, and basic tasks that are different from other organizations. The main purpose, function, and task of a Higher Union are to improve welfare or for the public interest, not for the benefit of a particular individual or group of people, but in reality, it is difficult to avoid such things, especially in dealing with the current economic situation. So, in its development plans, sometimes things that are not allowed to be done by nonprofit organizations such as Higher Education, such as publication efforts to attract more prospective students.

Ability/competence is the ability to behave, think, and act consistently as an embodiment of the knowledge, attitudes, and skills possessed, (Sa'ud \& Makmun, 2005). Whereas what is meant by the ability to manage the teaching and learning process is the ability or ability of lecturers to create an atmosphere of educational communication between lecturers and students which includes cognitive, affective and psychomotor aspects, as an effort to learn something based on planning up to the evaluation and followup stages to achieve teaching objectives. According to Sa'ud \& Makmun (2005) the ability of Lecturers refers to PP No. 19 of 2005 concerning National Education Standards and Law No. 14 of 2005 concerning Teachers 
and Lecturers, including:

Pedagogical Ability is the ability to manage learners' learning which includes the ability to design, manage, and assess learning: (a) able to understand the characteristics of students, (b) applying learning theory, learning theory relevant to students and in accordance with the characteristics of the subjects they have; (2) Able to manage learning in accordance with the characteristics of students: (a) able to design learning interactively, (b) inspirational, fun, challenging, motivating, students to participate actively, and provide sufficient space for initiative, creativity, and independence in accordance with the talents, interests and physical and psychological development of students; (3) Personality ability is a personality that is steady, stable, mature, wise, and wise, authoritative, being a role model for students, having good character, evaluating their own performance, developing themselves sustainably: (a) able to act consistently in accordance with the norms religion, law, social and national culture of Indonesia (b) able to present themselves as a person who is steady, stable, mature, wise, dignified, and has good character; (4) Having pride in being a lecturer, being able to work independently, having a work ethic, self-confidence, and high responsibility; (5) Social Ability, is the ability of lecturers which includes the ability to: (a) communicate verbally, in writing or in cues (b) use communication and information technology functionally (c) associate effectively with students, fellow educators, education personnel, people parents / guardians of students and socialize politely with the surrounding community; (6) There are professional capabilities that include: (a) mastery of learning material widely and deeply (b) the ability to design, implement and compile research reports, (c) the ability to develop and disseminate innovations in the fields of science, technology and / or art ; and (d) the ability to design, implement and assess community service.

Learning is a processing activity and is a very fundamental element in every level of education. In the whole educational process, learning activities are the most basic and important activities in the whole education process.

Learning is the process or effort made by each individual to obtain a change in behavior both in the form of knowledge, skills, and attitudes and positive values as an experience to get some impressions from the material that has been learned. Learning activities are carried out at school, at home, and in other places such as in museums, in laboratories, in the forest and everywhere. Learning is a complex student's action and behavior. As an action, learning is only experienced by students themselves and will be a determinant of the occurrence or non-occurrence of the learning process.

States learning is a business process carried out by someone to obtain a new change in behavior as a whole, as a result of his own experience in interaction with the environment. Abdillah further in Aunurrahman (2014) concluded that "learning is a conscious effort made by individuals in behavior change both through practice and experience concerning cognitive, affective, and psychomotor aspects to obtain certain goals".

According to the National Education System Law, Number 20 of 2012 states that learning is the process of interaction of students with educators and learning resources in a learning environment. From various opinions on the meaning of learning above, it can be concluded that learning is a process of activities that allows teachers to teach and students can receive subject matter taught by the teacher systematically and influence each other in teaching and learning activities to achieve the desired goals in a learning environment. The learning process is a communication process, namely the process of delivering messages from the message source through certain 
channels/media to the recipient of the message. Messages, message sources, channels/ media, and message recipients are components of the communication process. The process that will be communicated is the content of the teachings or education that is in the curriculum, the source of the message can be the teacher, students, other people, or authors of books and media. Likewise, the key to learning is with the teacher (instructor), but that does not mean that in the learning process only active teachers are passive students. Learning requires the activeness of both parties who are both subject to learning. So, if learning is marked by the activeness of the teacher while students are only passive, then, in essence, the activity is only called teaching. Likewise, if learning where students are active without involving the activeness of the teacher to manage it properly and directed, then it is only called learning. This shows that learning requires the activeness of teachers and students. Also, Abdillah (2012) concludes about the definition of learning, he states that learning is a conscious effort made by individuals in changing behavior both through practice and experience that involves aspects of cognitive, effective, and psychomotor to obtain certain goals.

According to Sardiman (2014) learning is a process of behavior change, and occurs because of the results of experience. In line with that, Agung (2012) said: learning is an effort made by someone through interaction with their environment to change their behavior. Kurniawan (2014) said learning is an active internal process of an individual where through his experience interacting with the environment causes changes in behavior that are relatively permanent. Meanwhile, according to Djamarah (2011) learning is a series of physical and mental activities to obtain a change in behavior as a result of an individual's experience in interactions with his environment involving cognitive, affective, and psychomotor.

METHODS
Quantitative research methods
using statistical tests, including
Correlation Analysis, Regression
Analysis, and Path Analysis. Correlation
analysis is a statistical technique used to
examine the presence/absence of a
relationship and the direction of the
relationship of two or more variables.
Regression Analysis is an advanced
analysis of Correlation, testing the
extent of the influence of independent
variables on the dependent variable.
Path Analysis is a development
technique of multiple linear regressions.

\section{RESULTS AND DISCUSSION}

The results of the study were arranged based on the results of hypothesis testing from each institution that was made the object of research using correlation analysis, regression, and path analysis.

\section{Hypothesis Test Results (Lecturer Respondents)}


Table 1. Hypothesis Test Results Lecturer Respondents PTS 1

\begin{tabular}{llrrr}
\hline & & $\begin{array}{c}\text { Correlations } \\
\text { Financing } \\
\text { Efficiency }\end{array}$ & $\begin{array}{c}\text { Lecturer } \\
\text { Performance }\end{array}$ & $\begin{array}{c}\text { Student Learning } \\
\text { Outcomes }\end{array}$ \\
\hline Financing & Pearson Correlation & 1 & $.883^{* *}$ & $.905^{* *}$ \\
Efficiency & Sig. (2-tailed) & 20 & .000 & .000 \\
& $N$ & 20 & 20 \\
Lecturer & Pearson Correlation & $.883^{* *}$ & 1 & $.982^{* *}$ \\
Performance & Sig. (2-tailed) & .000 & 20 & .000 \\
Student & $N$ & $.905^{* *}$ & $.982^{* *}$ & 20 \\
Learning & Pearson Correlation & .000 & .000 & 1 \\
Outcomes & Sig. (2-tailed) & 20 & 20 & 20 \\
$* *$ Correlation is significant at the 0.01 level (2-tailed). & & \\
\hline \multicolumn{5}{c}{ Source: data processed by the author (2020) }
\end{tabular}

Table 1 above shows that the Correlation Efficiency Coefficient and Lecturer Performance is 0,88 , while the Regression Determination Coefficient $\left(R^{2}\right)$ is 0,77 , this shows that the influence of Financing Efficiency on Lecturer Performance is Very Strong and
Significant, Correlation Coefficient Lecturer Performance and Student Learning Outcomes is 0,98 , while the Regression Coefficient $\left(R^{2}\right)$ is 0,96 , this shows that the relationship between Lecturer Performance and Student Learning Outcomes is Very Strong.

Tabel 2. Hypothesis Test Results Lecturer Respondents PTS 2

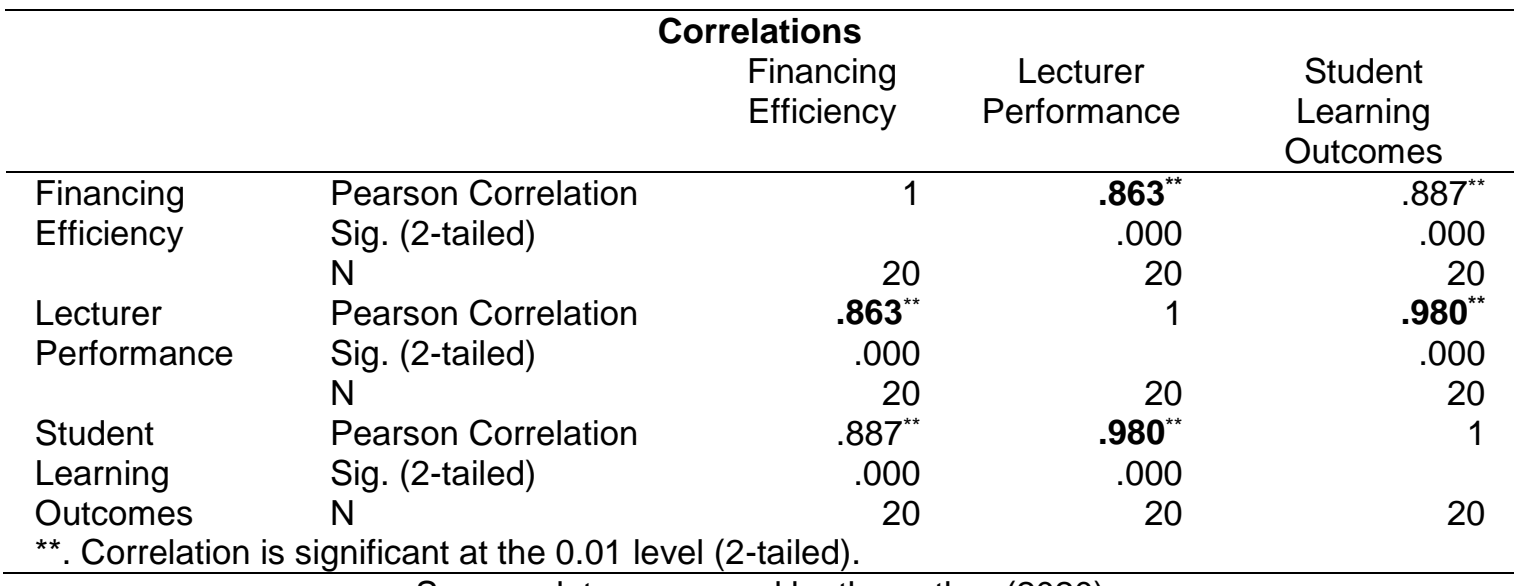

Source: data processed by the author (2020)

Table 2 above shows that the Correlation Coefficient of Financing Efficiency and Lecturer Performance is 0,86, while the Regression Determination Coefficient $\left(R^{2}\right)$ is 0,74 , this shows that the influence of Financing Efficiency on Lecturer Performance are Strong and Significant, Correlation Coefficient
Lecturers and Student Learning Outcomes are 0,98, while the Regression Coefficient $\left(R^{2}\right)$ is 0,96 , this shows that the relationship between Lecturer Performance and Student Learning Outcomes is Very Strong. 
Tabel 3. Hypothesis Test Results Lecturer Respondents PTS 3

\begin{tabular}{|c|c|c|c|c|}
\hline & & $\begin{array}{l}\text { lations } \\
\text { Financing } \\
\text { Efficiency }\end{array}$ & $\begin{array}{c}\text { Lecturer } \\
\text { Performance }\end{array}$ & $\begin{array}{c}\text { Student Learning } \\
\text { Outcomes }\end{array}$ \\
\hline Financing & Pearson Correlation & 1 & $.876^{\star \star}$ & $.879^{\star \star}$ \\
\hline \multirow[t]{2}{*}{ Efficiency } & Sig. (2-tailed) & & .000 & .000 \\
\hline & $\mathrm{N}$ & 20 & 20 & 20 \\
\hline Lecturer & Pearson Correlation & $.876^{* *}$ & 1 & $.955^{* \star}$ \\
\hline \multirow[t]{2}{*}{ Performance } & Sig. (2-tailed) & .000 & & .000 \\
\hline & $\mathrm{N}$ & 20 & 20 & 20 \\
\hline Student & Pearson Correlation & $879^{\star *}$ & $.955^{* *}$ & 1 \\
\hline Learning & Siq. (2-tailed) & .000 & .000 & \\
\hline $\begin{array}{l}\text { Outcomes } \\
\star \star \text {. Correlatior }\end{array}$ & $\begin{array}{l}\mathrm{N} \\
\text { hificant at the } 0.01 \mathrm{lev}\end{array}$ & 20 & 20 & 20 \\
\hline
\end{tabular}

Source: data processed by the author (2020)

Table 3 above, shows that the Financing Efficiency Correlation Coefficient and Lecturer Performance is 0,87, while the Regression Determination Coefficient $\left(R^{2}\right)$ is 0,77 , this shows that the effect of Financing Efficiency on Lecturer Performance is Strong and Significant, the Correlation
Coefficient of the direct relationship Lecturer Performance and Student Learning Outcomes is 0,95 , while the Regression Coefficient $\left(R^{2}\right)$ is 0,91 , this shows that the relationship between Lecturer Performance to Student Learning Outcomes is Very Strong.

Tabel 4. Hypothesis Test Results Lecturer Respondents PTS 4

\begin{tabular}{llrrr} 
& & $\begin{array}{c}\text { Correlations } \\
\text { Financing } \\
\text { Efficiency }\end{array}$ & $\begin{array}{c}\text { Lecturer } \\
\text { Performance }\end{array}$ & $\begin{array}{c}\text { Student Learning } \\
\text { Outcomes }\end{array}$ \\
\hline Financing & Pearson Correlation & 1 & $.838^{* *}$ & $.882^{* *}$ \\
Efficiency & Sig. (2-tailed) & .000 & .000 \\
& $N$ & 20 & 20 & 20 \\
Lecturer & Pearson Correlation & $.838^{* *}$ & 1 & $.947^{* *}$ \\
Performance & Sig. (2-tailed) & .000 & 20 & .000 \\
Student Learning & Pearson Correlation & 20 & $.947^{* *}$ & 20 \\
Outcomes & Sig. (2-tailed) & $.882^{* *}$ & .000 & 1 \\
& $N$ N & .000 & 20 & 21 \\
$* *$. Correlation is significant at the 0.01 level (2-tailed). & 20 & & \\
\hline
\end{tabular}

Source: data processed by the author (2020)

Table 4 above, shows that the Financing Efficiency Correlation Coefficient and Lecturer Performance is 0,84, while the Regression Determination Coefficient $\left(R^{2}\right)$ is 0,70 , this shows that the influence of Financing Efficiency on Lecturer Performance is Strong and Significant, the Correlation Coefficient of the Lecturer direct relationship Performance and Student Learning Outcomes is 0.95 , while the Regression Coefficient $\left(R^{2}\right)$ is
0,90 , this shows that the relationship between Lecturer Performance to Student Learning Outcomes is Very Strong.

\section{Hypothesis Test Results (Student Respondents)}


Tabel 5. Hypothesis Test Results Student Respondents (PTS 1)

\begin{tabular}{|c|c|c|c|c|}
\hline & & $\begin{array}{c}\text { Correlations } \\
\text { Financing } \\
\text { Efficiency } \\
\end{array}$ & $\begin{array}{c}\text { Lecturer } \\
\text { Performance }\end{array}$ & $\begin{array}{l}\text { Student Learning } \\
\text { Outcomes }\end{array}$ \\
\hline Financing & Pearson Correlation & 1 & $.863^{* *}$ & $.855^{*}$ \\
\hline \multirow[t]{2}{*}{ Efficiency } & Sig. (2-tailed) & & .000 & .000 \\
\hline & $\mathrm{N}$ & 50 & 50 & 50 \\
\hline Lecturer & Pearson Correlation & $.863^{\text {** }}$ & 1 & $.989^{* *}$ \\
\hline \multirow[t]{2}{*}{ Performance } & Sig. (2-tailed) & .000 & & .000 \\
\hline & $\mathrm{N}$ & 50 & 50 & 50 \\
\hline Student Learning & Pearson Correlation & $.855^{* *}$ & $.989^{* *}$ & 1 \\
\hline \multirow[t]{2}{*}{ Outcomes } & Sig. (2-tailed) & .000 & .000 & \\
\hline & $\mathrm{N}$ & 50 & 50 & 50 \\
\hline
\end{tabular}

Source: data processed by the author (2020)

Table 5 above, shows that the Financing Efficiency Correlation Coefficient and Lecturer Performance is 0.86, while the Regression Determination Coefficient (R2) is 0.74 , this shows that the effect of Financing Efficiency on Lecturer Performance is Strong and Significant, the
Correlation Coefficient of the Lecturer direct relationship Performance and Learning Outcomes are 0.99, while the Regression Coefficient (R2) is 0.98 , this shows that the relationship between Lecturer Performance and Learning Outcomes is Very Strong.

Tabel 6. Hypothesis Test Results Student Respondents (PTS 2)

\begin{tabular}{llrrr}
\hline & & $\begin{array}{c}\text { Correlations } \\
\text { Financing } \\
\text { Efficiency }\end{array}$ & $\begin{array}{c}\text { Lecturer } \\
\text { Performance }\end{array}$ & $\begin{array}{c}\text { Student Learning } \\
\text { Outcomes }\end{array}$ \\
\hline Financing & Pearson Correlation & 1 & $.909^{* *}$ & $.946^{* *}$ \\
Efficiency & Sig. (2-tailed) & 50 & .000 & .000 \\
& $\mathrm{~N}$ & $.909^{* *}$ & 50 & 50 \\
Lecturer & Pearson Correlation & .000 & 1 & $.973^{* *}$ \\
Performance & Sig. (2-tailed) & 50 & 50 & .000 \\
Student & $\mathrm{N}$ & $.946^{* *}$ & $.973^{* *}$ & 50 \\
Learning & Pearson Correlation & .000 & .000 & 1 \\
Outcomes & Sig. (2-tailed) & 50 & 50 & 50 \\
$* *$ Correlation is significant at the 0.01 level (2-tailed). & Source: data processed by the author (2020) \\
\hline \multicolumn{4}{c}{}
\end{tabular}

Table 6 above, shows that the Financing Efficiency Correlation Coefficient and Lecturer Performance is 0.91, while the Regression Determination Coefficient (R2) is 0.83 , this shows that the effect of Financing Efficiency on Lecturer Performance is Very Strong and Significant, the
Correlation Coefficient Lecturer Performance and Learning Outcomes are 0.97, while the Regression Coefficient (R2) is 0.95 , this shows that the relationship between Lecturer Performance and Learning Outcomes is Very Strong. 
Tabel 7. Hypothesis Test Results Student Respondents (PTS 3)

\begin{tabular}{|c|c|c|c|c|}
\hline & & $\begin{array}{l}\text { Correlations } \\
\text { Financing } \\
\text { Efficiency }\end{array}$ & $\begin{array}{c}\text { Lecturer } \\
\text { Performance }\end{array}$ & $\begin{array}{l}\text { Student } \\
\text { Learning } \\
\text { Outcomes }\end{array}$ \\
\hline Financing & Pearson & 1 & $.903^{* *}$ & $.924^{\star *}$ \\
\hline \multirow[t]{3}{*}{ Efficiency } & Correlation & & & \\
\hline & Sig. (2-tailed) & & .000 & .000 \\
\hline & $\mathrm{N}$ & 50 & 50 & 50 \\
\hline Lecturer & Pearson & $.903^{* *}$ & 1 & $.952^{* *}$ \\
\hline \multirow[t]{3}{*}{ Performance } & Correlation & & & \\
\hline & Sig. (2-tailed) & .000 & & .000 \\
\hline & $\mathrm{N}$ & 50 & 50 & 50 \\
\hline Student & Pearson & $.924^{* *}$ & $.952^{* *}$ & 1 \\
\hline Learning & Correlation & & & \\
\hline \multirow[t]{2}{*}{ Outcomes } & Sig. (2-tailed) & .000 & .000 & \\
\hline & $\mathrm{N}$ & 50 & 50 & 50 \\
\hline${ }^{\star \star}$. Correlatio & ignificant at the & l level (2-tailed) & & \\
\hline
\end{tabular}

Table 7 above, shows that the Financing Efficiency Correlation Coefficient and Lecturer Performance is 0.90, while the Regression Determination Coefficient (R2) is 0.82 , this shows that the effect of Financing Efficiency on Lecturer Performance is Very Strong and Significant, the
Correlation Coefficient of the direct relationship Lecturer Performance and Learning Outcomes are 0.95 , while the Regression Coefficient (R2) is 0.91 , this shows that the relationship between Lecturer Performance and Learning Outcomes is Very Strong.

Tabel 8. Hypothesis Test Results Student Respondents (PTS 4)

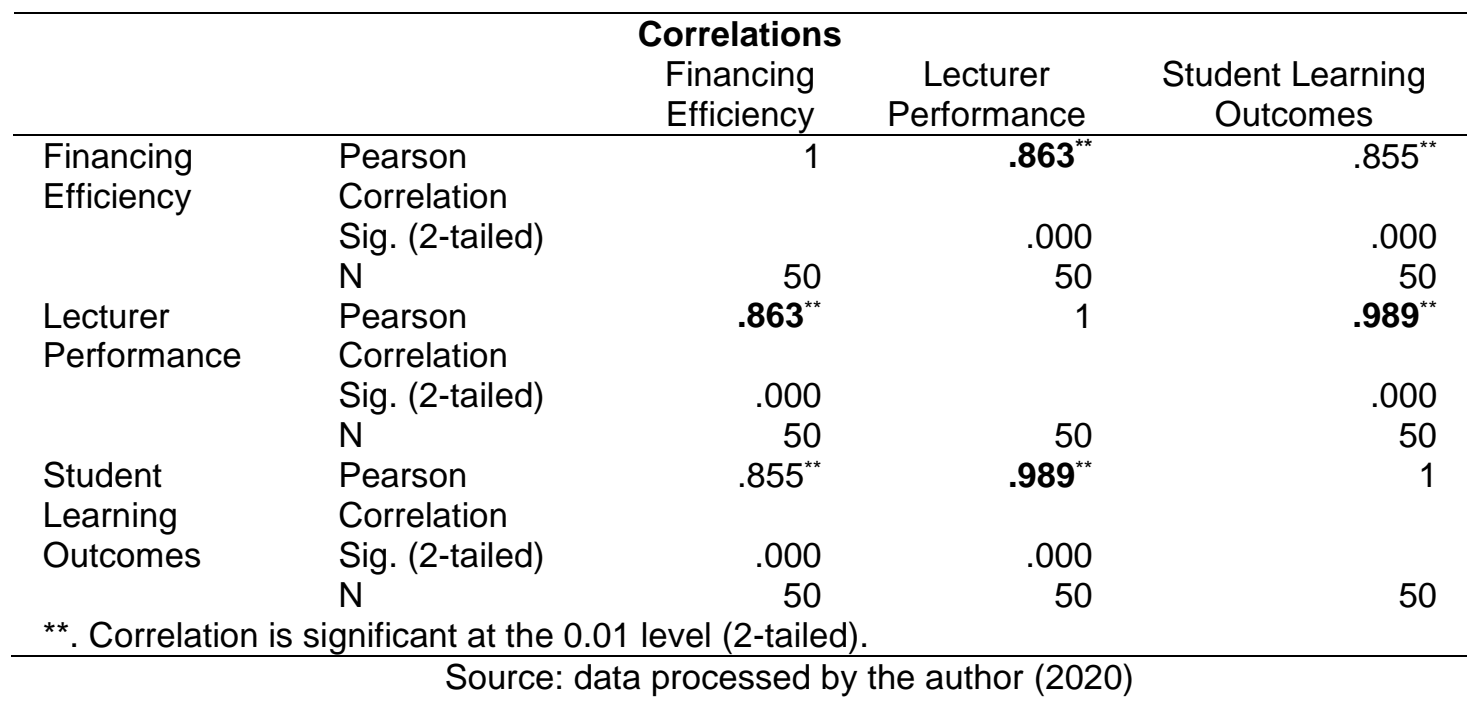

Table 8 above, shows that the Financing Efficiency Correlation Coefficient and Lecturer Performance is 0.86, while the Regression Determination Coefficient (R2) is 0.74 , this shows that the influence of
Financing Efficiency on Lecturer Performance is Strong and Significant, the Correlation Coefficient of the Lecturer direct relationship Performance and Learning Outcomes are 0.99 , while the Regression Coefficient (R2) is 0.98 , 
this shows that the relationship between Lecturer Performance and Learning Outcomes is Very Strong.

Based on the explanation above that are the object of research there are many similarities to the results of the discussion. (Lecturers' Perception) Education providers are demanded to always provide the best performance or are demanded to be better able to manage education, education management including financing issues, which will efficiently affect the implementation of learning in the Higher Education itself. (Student Perception) Efficient and effective financial management will have a significant impact on Lecturer Performance and Student Learning Outcomes.

\section{CONCLUSION}

Financing Efficiency is a matter that must get serious attention where all activities as a whole from an institution require financial support. Financing Efficiency for Private Universities is not only on strategic factors for implementing institutional programs but also specifically is an influential thing on Lecturer Performance which ultimately leads to Student Learning Outcomes.

The coefficient of determination of the efficient financing of Lecturer Performance and Lecturer Performance on Student Learning Outcomes obtained high numbers. This shows the Financing Efficiency factor is something that has been applied to the Institution that manages the financing which includes direct costs, indirect costs, be it development costs or routine costs. The Performance Lecturer for Student
Learning Outcomes illustrates that Financing Efficiency has been implemented effectively. The coefficient of determination of the effect of Financing Efficiency on Student Learning Outcomes obtained a small number because this efficiency factor does not directly affect Student Learning Outcomes.

\section{REFERENCES}

Abdillah, Fuad. (2012). Hubungan Kohevitas Kelompok Dengan Intensi Turnover. Pada Karyawan. Journal of Social and Industrial Psychology, 1(2), 52-58.Agung, Iskandar. (2012). Panduan Penelitian Tindakan Kelas bagi Guru. Jakarta: Bestari. Buana Murni.

Ahmad \& Wasilah. (2009). Akuntansi Biaya. Salemba Empat: Jakarta.

Aunurrahman. (2014). Belajar dan Pembelajaran. Bandung: Alfabeta

Bustami, Bastian \& Nurlela. (2009). Akuntansi Biaya. Edisi Pertama. Jakarta: Mitra Wacana Media.

Djamarah, Syaiful Bahri. (2011). Psikologi Belajar. Jakarta : Rineka Cipta.

Kurniawan, Albert. (2014). Metode Riset untuk Ekonomi dan Bisnis. Bandung: CV. Alfabeta.

Sardiman. (2014). Interaksi dan Motivasi Belajar-Mengajar. Jakarta: PT. RajaGrafindo Persada.

Sa'ud, Syaefudin \& Makmun, Abin Syamsudin. (2005). Perencanaan Pendidikan. Suatu pendekatan Komprehensif. Bandung: PT. Remaja Rosdakarya. 